\title{
The Effects of Vitex trifolia, Strobilanthes crispus and Aloe vera Herbal-mixed Dietary Supplementation on Growth Performance and Disease Resistance in Red Hybrid Tilapia (Oreochromis sp.)
}

Sharifah Raina Manaf ${ }^{1,4}$, Hassan Mohd. Daud ${ }^{1,3 *}$, Abdul Razak Alimon ${ }^{2}$, Noordin Mohamed Mustapha', Ruhil Hayati Hamdan', Kumari Geetha Muniandy ${ }^{3}$, Nora Faten Afifah Mohamed ${ }^{1}$, Rashidah Razak ${ }^{1}$ and Nur Hidayahanum Hamid ${ }^{1}$

${ }^{1}$ Faculty of Veterinary Medicine, Universiti Putra Malaysia, Serdang, Selangor, Malaysia

${ }^{2}$ Faculty of Agriculture, Universiti Putra Malaysia, Serdang, Selangor, Malaysia

${ }^{3}$ Institute of Bioscience, Universiti Putra Malaysia, Serdang, Selangor, Malaysia

${ }^{4}$ Faculty of Plantation and Agrotechnology, University Technology Mara (Melaka), Jasin Campus, Merlimau, Melaka, Malaysia

\begin{abstract}
Herbs and herb mixtures have been used as a growth promotant in livestock and aquaculture production The objective of the study was to evaluate the effect of a dietary herbal mix comprised of Vitex trifolia (VTE), Strobilanthes crispus (SCE) and Aloe vera (AVE) on the growth performance, disease resistance and histology of Oreochromis sp. for 60 days. The fishes were divided into i) control, infected fish, fed with normal diet and infected fishes treated with different herbal-mixed supplementation diets of ii) VTE and SCE iii) SCE and AVE iv) AVE and VTE. All experimental groups were challenged using with Streptococcus agalactiae $\left(1 \times 10^{7} \mathrm{cfu} / \mathrm{mL}\right)$ via intraperitoneal route on day 46 . On day $46^{\text {th }}$ (pre-challenge) and $60^{\text {th }}$ (post-challenge), five fish were randomly chosen from each tank for each experimental and control groups to blood collection. The cumulative mortality and survival rate were assessed every day. Tissues from kidney, liver and spleen were examined. The fish supplemented with herbal-mix with the combination of VTE and SCE and AVE and VTE showed improved growth performance. For haematological assays, RBC, $\mathrm{Hb}$, and WBC were higher $(P<0.05)$ in fish supplemented with these herb mix, while the alanine aminotransferase (ALT) and alkaline phosphatase (ALP) were significantly affected by mixed-herbal supplementation. Histopathological examination of the organs revealed no negative effects in tissues. In conclusion this study suggested that methanolic extracts of herbal mix composed of $V$. trifolia, S. crispus and $A$. vera extracts were effective as growth promoters and bacterial disease treatment in Oreochromis $\mathrm{sp}$. when supplemented in daily diet.
\end{abstract}

Keywords: Vitex trifolia; Strobilanthes crispus; Aloe vera; Growth performance; Red tilapia; Bacterial resistance; Herbs

\section{Introduction}

Feed additives are substances which are added in small amounts into animal feeds to serve functions other than nutrient supply [1]. These additives are known to improve growth performance through improved feed utilization, reduction of pathogenic bacteria in the gastro-intestinal tract, and production of metabolites that improve animal metabolism. Additives are also used in aquaculture for increased growth performance and reduction of mortality in fish. The most used growth promoting feed additives in animal and aqua feeds are hormones, antibiotics, ionospheres and some salts [2]. Recently, some studies showed the positive effects of dietary medicinal plants or herbs as feed additives on the fish and crayfish growth and their feed utilization [3]. Attempts to use the natural materials such as medicinal plants could be widely accepted as feed additives to enhance feed utilization and aquaculture production [4].

It is a well-known fact about medicinal or herb benefit as feed additives for humans and animals, such antimicrobial and health procuress [5]. However mixed herbs are also options to overcome disease problem, because using single plant may compliment certain shortcomings such as inadequacy of nutrient and phytochemical properties. Moreover, World Health Organization encourages the usage of medicinal plants or herbs to substitute or minimize the use of chemicals through the global trend of going back to the nature. However, there is no report on herbal-mixed extracts in dietary supplementation for Oreochromis sp. on growth, haematological response and diseases resistance against Streptococcus agalactiae.

\section{Materials and Methods}

\section{Preparation of herbs and methanolic extraction}

Vitex trifolia, Aloe vera and Strobilanthes crispus were obtained from University Agriculture Park, University Putra Malaysia, Selangor, Malaysia. Fresh healthy leaves, stems and including flowers were collected in morning and washed under running tap water to remove dirt particles. They were allowed to dry in a forced-draught oven at a temperature of $65^{\circ} \mathrm{C}$ for $48 \mathrm{~h}$. They were then chopped into small pieces and ground into powder using mechanical grinder (Panasonic, MY333). The powdered plant materials were kept in airtight bottles at room temperature prior to extraction. Methanol extracts were prepared by adding $100 \mathrm{~g}$ of plants powder into $1000 \mathrm{~mL}$ of $70 \%$ of solvents and agitated for $72 \mathrm{~h}$ at ambient temperature in a shaking incubator. Then, the extracts were filtered through $11 \mu \mathrm{m}$ membrane filter paper (Whatman No. 1). After that, the extracts were evaporated to dryness using rotary evaporator at $40^{\circ} \mathrm{C}$. The methanol extracts were dissolved

*Corresponding author: Hassan Mohd. Daud, Faculty of Veterinary Medicine Universiti Putra Malaysia, Serdang, Selangor, Malaysia, Tel: +60389468286 E-mail: hassanmd@upm.edu.my

Received January 18, 2016; Accepted April 28, 2016; Published April 30, 2016

Citation: Manaf SR, Daud HM, Alimon AR, Mustapha NM, Hamdan RH, et al (2016) The Effects of Vitex trifolia, Strobilanthes crispus and Aloe vera Herbalmixed Dietary Supplementation on Growth Performance and Disease Resistance in Red Hybrid Tilapia (Oreochromis sp.). J Aquac Res Development. 7: 425. doi:10.4172/2155-9546.1000425

Copyright: (C) 2016 Manaf SR, et al. This is an open-access article distributed under the terms of the Creative Commons Attribution License, which permits unrestricted use, distribution, and reproduction in any medium, provided the original author and source are credited. 
Citation: Manaf SR, Daud HM, Alimon AR, Mustapha NM, Hamdan RH, et al. (2016) The Effects of Vitex trifolia, Strobilanthes crispus and Aloe vera Herbal-mixed Dietary Supplementation on Growth Performance and Disease Resistance in Red Hybrid Tilapia (Oreochromis sp.). J Aquac Res Development. 7: 425. doi:10.4172/2155-9546.1000425

Page 2 of 5

again in $70 \%$ methanol to make a $0.5 \mathrm{~g} / \mathrm{mL}$ stock solution and stored at $-20^{\circ} \mathrm{C}$ until further use.

\section{Diets and experimental design}

The experiments were conducted at an Aquatic Animal Health Unit, Faculty of Veterinary Medicine, University Putra Malaysia. Oreochromis sp. fry were obtained from a local supplier. They were allowed two weeks for adaptation before they were allotted to the different dietary treatments. During the adaptation period they were given a commercial starter diet fed to satiation twice a day. After the adaptation period, 390 fishes (weighing about $120 \pm 0.5 \mathrm{~g}$ ) were randomly distributed into $100 \mathrm{~L}$ tanks (10 fishes per tank) containing aerated recirculated freshwater. Each treatment had three replicates and the fish were fed over a period of 60 days. A non-stop aeration to maintain the dissolved oxygen to the optimal level was provided. All fish were fed twice daily at $4 \%$ of body weight and the daily ration was adjusted accordingly. The feed consumption in each aquarium was recorded daily. Dead fishes from each aquarium were collected daily and weighed.

In this experiment, a commercial starter diet was used as a basal diet. The dietary treatments were basal diet supplemented with three extracts from herbs, namely, V. trifolia (VTE), A. vera (AVE) and S. crispus (SCE). The control diet does not contain any herbal extract. A control diet was formulated according to NRC [6] recommendation and contained $35 \%$ crude protein and $3493 \mathrm{kcal}$ of digestible energy $\mathrm{kg}^{-1}$ of dietary dry matter (DM). Additional three diets were formulated as commercial diet supplemented with $3.5 \mathrm{~g} \mathrm{VTE} / \mathrm{kg} \mathrm{DM}+3.5 \mathrm{~g} \mathrm{SCE} /$ $\mathrm{kg}$ DM (VTE and SCE), 3.5g VTE/kg DM + 3.5g AVE/kg DM (VTE and AVE) and 3.5g AVE/kg DM + 3.5 g SCE/kg DM (AVE and SCE) which prepared. Distilled deionized water was added into each diet and mixed [7]. The diets were air-dried at ambient temperature for $72 \mathrm{~h}$, packed in air-tight containers, labelled and stored.

\section{Growth performance}

Fish were weighed at the beginning and at the end of the experiment, and the growth performance and feed utilization were assessed on weight gain (WG), specific growth rate (SGR) and feed conversion ratio (FCR) [8].

\section{Challenge assay}

After feeding the fish with VTE, AVE and SCE for 45 days, the fish in subgroup will be tested by challenge test. The challenge was made by intraperitoneal injection with $0.1 / \mathrm{ml}$ suspensions of $S$. agalactiae in $0.9 \%(\mathrm{w} / \mathrm{v})$ saline containing $10^{7}$ cells $/ \mathrm{mL}$. The percentage survival in each treatment was calculated as previously described by Akinwole $\mathrm{AO}$, et al. [9] using the following modified formulae:

Survival rate $\%=($ Total no. of fish stocked - No. of fish died $) \times 100$

$$
\text { Total no. of fish stocked }
$$

\section{Haematological assessment}

On day $46^{\text {th }}$ (pre-challenge) and 60th (post-challenge), five fish were randomly chosen from each tank for each experimental and control groups and were anaesthetized with tricane methane sulfate (MS222) at $150 \mathrm{mg} / \mathrm{L}$ prior to blood collection after $24 \mathrm{~h}$ of final feeding for. The blood samples were collected by puncturing the caudal vein by using a 25G X 1 syringe and transferred into lithium heparin tubes. The collected blood samples were immediately subjected to haematological analysis. Evaluation of the haemogram involves the determination of the Red Blood Count (RBC), Haematocrit (Hct),
Hemoglobin concentration (Hb), White Blood Cell Count (WBC), Mean Corpuscular Volume (MCV), Mean Corpuscular Haemoglobin $(\mathrm{MCH})$, and Mean Corpuscular Haemoglobin Concentration (MCHC). The blood enzyme measurement in Alkaline phosphatase (ALP), Alkaline transeaminase (ALT) and Aspartate transeaminase (AST). An automatic blood enzyme analyzer (Hitachi 704) was used for the following determinations: Alkaline phosphatase (ALP, U/L), Alkaline transeaminase (ALT, U/L) and Aspartate transeaminase (AST, U/L). The apparatus is based upon dry chemical technology and colorimetric reaction. Kits obtained PLIVA- Lachema and DIALAB', were used for the determination of all indices. Also for controls, same kits were used. The hematological and biochemical parameters are expressed in international units (SI).

\section{Histopathological assessment}

For histology, fish were euthanized with MS-222 and liver, kidney, spleen and brain were immediately collected. Tissues were fixed in $10 \%$ buffered formalin for at least $24 \mathrm{~h}$ and agitated in incubator shaker. Afterward, the tissues were transferred into new buffered formalin solution. The fixed tissues were processed in automated tissue processor. Then, the tissues were embedded in paraffin block for easy to store and handle. Sectioning using microtome to produce very thin, $4 \mu \mathrm{m}$ sections that are placed on a microscope slide ready for staining. Finally, the tissues were stained with haematoxylin and eosin and observed under light microscope. The histologic examination to detect any possible pathologic changes resulting from local or systemic disease

\section{Statistical analysis}

Data (initial weight, final weight, weight gain, initial length, final length, total length, SGR, FCR, SR and haematological indices) were analyzed using one-way analysis of variance (ANOVA) and significant differences among treatment means were compared using Duncan's multiple range test [10]. Significance was tested at 5\% level and all statistical analyses were carried out using the SPSS Version 21.

\section{Results and Discussion}

Table 1 shows the growth performance of Oreochromis sp. fed diets supplemented with herbal-mix for 60 days. The fingerling with average $12 \mathrm{~g}$ and initial length $12 \mathrm{~cm}$ used were used to determine the beneficial effect of the chosen mixed herb.

Means with the same superscript in rows were not significantly different at $\mathrm{P}<0.05$. Values in parentheses are standard errors of means. $\mathrm{SGR}=$ specific growth rate, $\mathrm{FCR}=$ feed conversion ratio

Herbal-mixed supplementation showed improved growth performance in fish fed with the combination of VTE and SCE and AVE and VTE as compared to the control group. Final weight and body weight gain, showed increased significantly $(\mathrm{P}<0.05)$ in the all mixedherbal compared to the control group. AVE and VTE showed the most significant growth compared to other fed mixed herbs combination. The lowest fish growth was obtained in AVE and SCE diet. Moreover, fish fed on diets containing AVE and VTE and VTE and SCE showed the optimum FCR with 1.16 and 1.10 respectively, whereas fish fed with control group produced higher FCR, 1.33. The total length was significantly different between treatments except with the AVE and SCE. However, for SGR the growth performances resulted with AVE and SCE and VTE and SCE combination was significantly lower ( $\mathrm{P}>0.05)$ compared to the control group.

Only AVE and VTE showed promising result with significantly 
Citation: Manaf SR, Daud HM, Alimon AR, Mustapha NM, Hamdan RH, et al. (2016) The Effects of Vitex trifolia, Strobilanthes crispus and Aloe vera Herbal-mixed Dietary Supplementation on Growth Performance and Disease Resistance in Red Hybrid Tilapia (Oreochromis sp.). J Aquac Res Development. 7: 425. doi:10.4172/2155-9546.1000425

Page 3 of 5

\begin{tabular}{|c|c|c|c|c|}
\hline & \multicolumn{4}{|c|}{ Diets } \\
\hline & C & AVE \& SCE & AVE \& VTE & VTE \& SCE \\
\hline Initial weight (g) & $12.07 \pm 0.65^{a}$ & $12.06 \pm 0.40^{a}$ & $12.09 \pm 0.05^{a}$ & $12.08 \pm 0.65^{a}$ \\
\hline Final weight $(\mathrm{g})$ & $19.34 \pm 0.09^{a}$ & $21.59 \pm 0.67^{\mathrm{b}}$ & $24.58 \pm 0.08^{d}$ & $24.19 \pm 0.73^{c}$ \\
\hline Weight gain $(\mathrm{g})$ & $60.32 \pm 0.93^{a}$ & $78.97 \pm 0.04^{b}$ & $103.29 \pm 0.61^{d}$ & $100.27 \pm 0.52^{c}$ \\
\hline Initial length $(\mathrm{cm})$ & $11.95 \pm 0.00^{\mathrm{a}}$ & $11.78 \pm 0.75^{\mathrm{a}}$ & $12.00 \pm 2.50^{\mathrm{a}}$ & $12.10 \pm 2.5^{a}$ \\
\hline Final length & $13.12 \pm 0.08^{\mathrm{a}}$ & $13.11 \pm 0.53^{a}$ & $15.55 \pm 3.23^{b}$ & $15.08 \pm 3.75^{\mathrm{b}}$ \\
\hline Specific Growth Rate (SGR) (\%) & $10.90 \pm 0.04^{b}$ & $10.10 \pm 0.06^{a}$ & $11.00 \pm 0.04^{b}$ & $10.71 \pm 0.20^{b}$ \\
\hline Feed Conversion Ratio (FCR) & $1.33 \pm 0.00^{\mathrm{d}}$ & $1.27 \pm 0.01^{c}$ & $1.16 \pm 0.00^{b}$ & $1.10 \pm 0.00^{\mathrm{a}}$ \\
\hline Survival (\%) & $90.00 \pm 0.00^{\mathrm{a}}$ & $97.50 \pm 2.5^{\mathrm{b}}$ & $100 \pm 0.00^{b}$ & $100 \pm 0.00^{\mathrm{b}}$ \\
\hline
\end{tabular}

Table 1: Mean growth performance and feed utilization of Oreochromis sp. fingerlings fed commercial diet supplemented with herbal-mix diets for 60 days.

\begin{tabular}{|c|c|c|c|c|c|c|c|c|}
\hline \multirow[t]{3}{*}{ Day } & \multicolumn{2}{|c|}{ Diets } & & & & & & \\
\hline & \multicolumn{2}{|c|}{ C } & \multicolumn{2}{|c|}{ AVE\&SCE } & \multicolumn{2}{|c|}{ AVE\&VTE } & \multicolumn{2}{|c|}{ VTE\&SCE } \\
\hline & 45 (Pre-challenge) & 60 (Post-challenge) & 45 (Pre-challenge) & 60 (Post-challenge) & 45 (Pre-challenge) & 60 (Post-challenge) & 45 (Pre-challenge) & 60 (Pre-challenge) \\
\hline $\begin{array}{l}\text { RBC } \\
\left(x \quad 10^{12} / L\right)\end{array}$ & $1.18 \pm 0.01^{\mathrm{a}}$ & $1.38 \pm 0.02^{\mathrm{b}, \mathrm{c}}$ & $1.29 \pm 0.01^{b}$ & $2.10 \pm 0.06^{d}$ & $1.66 \pm 0.01^{c}$ & $2.24 \pm 0.01^{\mathrm{e}}$ & $1.51 \pm 0.05^{c}$ & $2.05 \pm 0.01^{d}$ \\
\hline $\mathrm{Hb}(\mathrm{g} / \mathrm{L})$ & $66.2 \pm 5.30^{b}$ & $62.8 \pm 1.40^{\mathrm{a}, \mathrm{b}}$ & $57 \pm 1.40^{a}$ & $86.65 \pm 0.75^{c}$ & $66.95 \pm 2.35^{\mathrm{a}}$ & $90.9 \pm 0.20^{c}$ & $66.8 \pm 1.30^{\mathrm{a}}$ & $83.8 \pm 1.00^{c}$ \\
\hline $\begin{array}{l}\text { WBC } \\
\left(\times 10^{9} / L\right)\end{array}$ & $1.29 \pm 0.05^{\mathrm{a}}$ & $6.80 \pm 0.01^{c}$ & $3.49 \pm 0.32^{b}$ & $15.95 \pm 0.55^{\mathrm{e}}$ & $3.32 \pm 0.12^{b}$ & $16.00 \pm 0.50^{e}$ & $3.35 \pm 0.13^{b}$ & $11.52 \pm 0.02^{d}$ \\
\hline PCV (L/L) & $0.17 \pm 0.020^{\mathrm{a}}$ & $0.20 \pm 0.01^{\mathrm{a}, \mathrm{b}}$ & $0.17 \pm 0.03^{a}$ & $0.23 \pm 0.01^{b}$ & $0.15 \pm 0.04^{a}$ & $0.23 \pm 0.01^{b}$ & $0.18 \pm 0.01^{a, b}$ & $0.24 \pm 0.01^{b}$ \\
\hline MCV (fL) & $108.5 \pm 0.50^{\mathrm{a}, \mathrm{b}}$ & $107.5 \pm 1.50^{\mathrm{b}}$ & $106.5 \pm 1.00^{\mathrm{a}}$ & $105.5 \pm 1.50^{\mathrm{a}}$ & $119.5 \pm 0.50^{c}$ & $107.5 \pm 0.50^{\mathrm{b}}$ & $115.5 \pm 2.50^{b}$ & $112.5 \pm 1.00^{\mathrm{a}, \mathrm{b}}$ \\
\hline $\mathrm{MCHC}(\mathrm{g} / \mathrm{L})$ & $401.5 \pm 1.50^{e}$ & $370.5 \pm 0.50^{b}$ & $405 \pm 2.00^{f}$ & $393 \pm 2.50^{c}$ & $395 \pm 2.50^{\mathrm{e}}$ & $375 \pm 1.00^{\text {c.d }}$ & $399 \pm 2.00^{\mathrm{d}, \mathrm{e}}$ & $355.5 \pm 0.50^{\mathrm{a}}$ \\
\hline $\begin{array}{l}\text { Thrombocyte } \\
\text { (x 10\%/L) }\end{array}$ & $10.05 \pm 0.05^{a}$ & $16.7 \pm 1.40^{\mathrm{b}}$ & $9.45 \pm 0.35^{\mathrm{a}}$ & $16.65 \pm 0.95^{b}$ & $10.75 \pm 0.05^{\mathrm{a}}$ & $10.35 \pm 0.15^{a}$ & $9.25 \pm 0.05 a$ & $35.8 \pm 1.00^{c}$ \\
\hline $\operatorname{ALT}(\mathrm{U} / \mathrm{L})$ & $43.45 \pm 0.95^{9}$ & $38.85 \pm 0.95^{f}$ & $21.75 \pm 1.15^{c}$ & $12.5 \pm 0.20^{a}$ & $32.5 \pm 1.20^{d}$ & $21.85 \pm 0.45^{c}$ & $35.1 \pm 0.10^{e}$ & $15.95 \pm 0.45^{b}$ \\
\hline AST (U/L) & $43.00 \pm 1.00^{b, c}$ & $42.00 \pm 2.00^{b}$ & $47.5 \pm 0.50^{\mathrm{e}}$ & $46.00 \pm 1.00^{\mathrm{d}, \mathrm{e}}$ & $37.00 \pm 1.00^{\mathrm{a}}$ & $44.00 \pm 1.00^{\mathrm{b}, \mathrm{c.d}}$ & $40.50 \pm 0.50^{\mathrm{a}, \mathrm{b}}$ & $46.00 \pm 1.00^{\mathrm{d}, \mathrm{e}}$ \\
\hline ALP (U/L) & $302.4 \pm 2.30^{f}$ & $335.65 \pm 2.45^{9}$ & $303.9 \pm 1.60^{f}$ & $247.85 \pm 2.45^{\mathrm{e}}$ & $239.65 \pm 1.05^{d}$ & $154.2 \pm 1.40^{\mathrm{a}}$ & $222.95 \pm 0.05^{c}$ & $204.3 \pm 2.1^{b}$ \\
\hline
\end{tabular}

Table 2: Haematological characteristics of Oreochromis sp. fed experimental diets with herbal-mixed.

higher $(\mathrm{P}<0.05)$ compared to the control group. Fish survival rate after the diseases challenge ranges from $90 \%$ to $100 \%$ with significant difference $(\mathrm{P}<0.05)$ among all treatments including control treatment.

Means in a given rows with the same superscript letter were not significantly different at $\mathrm{P}<0.05$. Values in parentheses are standard errors of means. $\mathrm{PCV}=$ packed cell volume, $\mathrm{Hb}=$ haemoglobin, $\mathrm{WBC}=$ white blood cell count, $\mathrm{RBC}=$ red blood cell count, $\mathrm{TC}=$ thrombocyte count, $\mathrm{MCV}=$ mean corpuscular volume, $\mathrm{MCHC}=$ mean corpuscular haemoglobin concentration, $\mathrm{P}$. protein = plasma protein, $\mathrm{ALT}=$ alanine aminotransferase, $\mathrm{ALP}=$ alkaline phosphatase, $\mathrm{AST}=$ aspartate aminotransferase

Table 2 shows haematological parameters pre and post challenge after 45 days of continuous feeding after the diseases challenge. RBC, $\mathrm{Hb}$, and $\mathrm{WBC}$ showed higher significant difference $(\mathrm{P}<0.05)$ compared to control treatment. In the other hand, PCV did not show any significant difference among all the tested treatments. As for MCV and MCHC results, all mixed herbs showed significant different $(\mathrm{P}<0.05)$ except in AVEandSCE. Thrombocyte showed no significant difference in all treatments after feeding with experimental diets. Level of RBC increased after post-challenge for all treatments. Hb level of AVE and SCE, AVE and VTE, VTE and SCE and control at day 60 were $86.65 \pm 0.75 \mathrm{~g} / \mathrm{dL}, 90.9 \pm 0.2 \mathrm{~g} / \mathrm{dL} 83.8 \pm 1.00 \mathrm{~g} / \mathrm{dL}$ and $62.8 \pm 1.4 \mathrm{~g} / \mathrm{dL}$ respectively, showed that tremendous increase statistical was reported $(\mathrm{P}<0.05)$ from data at day $46(\mathrm{Hb}: 57 \pm 1.4 \mathrm{~g} / \mathrm{dL} ; 66.95 \pm 2.35 \mathrm{~g} / \mathrm{dL}$; $66.8 \pm 1.3 \mathrm{~g} / \mathrm{dL}$ and $66.2 \pm 5.3 \mathrm{~g} / \mathrm{dL})$. The WBC post challenge were significantly increased $(\mathrm{P}<0.05)$ at day 60 with a higher $16.00 \pm 0.50$ cells $/ \mathrm{mm}^{3}$ exhibited by AVE and VTE. Likewise, after the infection, the haematological indices like PCV, MCV (Table 2) resulted with no significant difference $(\mathrm{P}>0.05)$. On the other hand, $\mathrm{MCHC}$ results on days 60 were significantly difference $(\mathrm{P}<0.05)$ compared to the control group. The thrombocyte showed no significant difference only with AVE and SCE treatment.

The biochemical parameter of ALT and ALP were significantly affected by mixed-herbal supplementation. Pre-challenge of ALT showed significant difference in all treatments, compared to significant decreases at post challenge. However at the pre-challenge of ALP revealed only AVE and SCE with no significantly difference compared to control. Then at the post-challenge all mixed herb showed decreases in ALP value, however control treatment showed significant increases. There was a significantly $(\mathrm{P}<0.05)$ decrease in ALT and ALP postchallenge, compared with control. The AST showed significant different among all treatment, while control treatment did not show any significant difference at pre and post challenge. Post-challenge for AVE and VTE showed no significant difference compared to control.

\section{Discussion}

Streptococcosis is considered as the most overwhelming disease, causing massive death of fishes and is responsible for heavy economic losses. The use of antibiotics is the most effective way of treating a Streptococcosis disease. However, treating microbial infections in fish and shrimp larvae involves dissolving higher quantities of broad spectrum of chemotherapeutic agents in the culture medium [11]. The disadvantage of this method is the requirement of large amount of expensive drugs, which are used and discharged in the environment posing risk to the animals and human health. As an alternative, antimicrobial characteristic from natural source are used instead of synthetic antibiotic drugs. Several herbs have been tested for their growth promoting activity in aquatic animals [12,13]. In this study, combinations of selected herbs were subjected to the growth and health assessment of the tested fish, Oreochromis sp. The fish were fed with 
Citation: Manaf SR, Daud HM, Alimon AR, Mustapha NM, Hamdan RH, et al. (2016) The Effects of Vitex trifolia, Strobilanthes crispus and Aloe vera Herbal-mixed Dietary Supplementation on Growth Performance and Disease Resistance in Red Hybrid Tilapia (Oreochromis sp.). J Aquac Res Development. 7: 425. doi:10.4172/2155-9546.1000425

mixed-herbal of VTE and SCE, AVE and VTE, and AVE and SCE at the concentrations of $7 \mathrm{~g} / \mathrm{kg}$ diet, showed significantly improved in Oreochromis sp. growth and survival rate compared to control treatments. The final weight and body weight gain of the mixed-herbal supplemented, showed significant increase compared to control fed. This is supported by [14] study, who founded the feed additives from botanical extracts were able to enhance the digestibility or utilization efficiency of nutrients, including exogenous enzymes, stimulators of enzyme secretion, aid the digestive process by improving absorption, mobilization and transport of nutrients.

The most promising growth performances were exhibited by AVE and VTE, followed by VTE and SCE and AVE and SCE respectively. These results supported by [12], showed that significantly increase of the growth and survival rate during stressed conditions of Penaeus monodon [15] fed enriched Artemia with five herbal combination (Hygrophila spinosa, Withania somnifera, Zingiber officinalis, Solanum trilobatum, Andrographis paniculata, and Psoralea corylifolia) was reported.

Furthermore Ji SC, et al. [16] reported that other than the usage of different single herbal extracts (Massa medicata, Crataegi fructus, Artemisia capillaries and Cnidium officinale) or the mixture of the herbs also promoted growth and enhanced some non-specific immunity indicators in red sea bream (Pagrus major). AVE and VTE showed the most significant growth compared with other fed mixed herbs combination. The lowest fish growth was obtained in AVE and SCE diet. The phytochemical profile of VTE consists of the tannins, flavonoid and glysocide [17]. In contrast, AVE [18] and SCE [19] contain alkaloids, tannins and flavonoids. This phytochemical profile may be the reason for the improved growth performances in Oreochromis sp. as indicated in this study. This is consistent with [20], who identified the treatment with mixed-herbal formulations may confer with synergistic, potentiate the agonistic/antagonistic pharmacological activity. Synergism is generally dependent on the number of extracts, the dose and the various active compound combinations such as phenolic, flavonoids, alkaloids, terpenoids and tannins.

Moreover, fish fed on diets containing AVE and VTE and VTE and SCE showed the optimum FCR with 1.16 and 1.10 respectively, whereas fish fed with control diet produced higher FCR, 1.33. This is also supported by [21], with study on Nile tilapia supplemented with a mixture of herbal extracts, resulting in natural emulsifying agents and co-factors of digestion for better feed conversion and protein efficiency. However, for SGR data with AVE and SCE and VTE and SCE combination showed significantly lower $(\mathrm{P}>0.05)$ than compared to the control group. Nevertheless, AVE and VTE were able to show promising result with significantly higher $(\mathrm{P}<0.05)$ than compared to the control group. This also suggested that the correct doses and formulas to ensure the safety and efficacy of the mixed-herb, other than the optimum ratio of each single herb also must be clearly specified $[12,22,23]$. However, the concentration of herb incorporated does not significantly influence the growth and survival rate supported by [24]. The right proportion is important when using mixed-herbs as feed additives. Fish survival after the diseases challenge range from $90 \%$ to $100 \%$ with significant difference $(\mathrm{P}<0.05)$ among all treatments including control treatment. Ponpornpisit A, et al. [25] fed a Chinese herbal mix, known as C-UPIII, to the guppies (Lebistes reticulata) and observed an improved survival rate in fish infected with Tetrahymena pyriformis. Furthermore, the addition of a mixture of Chinese herbs (Rheum officinale, Andrographis paniculata, Isatis indigotica, Lonicera japonica) to the feed of crucian carp resulted in increased phagocytosis
[26], suggesting better microbial resistance. Moreover, the herbal-mix boosted the immune system in fish and shrimps against pathogenic infections. In cases where disease outbreaks are cyclical and could be predicted, immunostimulants may be used in anticipation of events to elevate the nonspecific defence mechanism, and thus prevent losses from diseases. It has been proven that immunostimulant herbal extracts as feed additives such as Cynodon dactylon, Phyllanthus niruri, Tridax procumbens, Zingiber officinalis, Ocimum sanctum, W. somnifera and Myristica fragrans have improved the immune system in grouper $E$. tauvina, while also at the same time controlling V. harveyi $[23,27]$.

The haematological and biochemical profiles of pre and post challenge infected groups (Table 2) were compared with the control group. $\mathrm{RBC}, \mathrm{Hb}$, and $\mathrm{WBC}$ showed higher significant difference $(\mathrm{P}<0.05)$ compare to control treatment. However, Nya EJ, et al. [28] reported that rainbow trout Oncorhynchus mykiss infected withVA. hydrophila, leading to increase of WBC and causing lead to anaemia, attributed to increased destruction, loss, or suppression of RBCs. However, in the present study, RBC and WBC showed significant differences at pre and post challenge showing the capability of the feed additive in bacteria disease resistance. This is also supported with the increase levels of WBC in A. hydrophila infected goldfish [29]. Further, by enhancing the WBC levels, the herbal treatment may have a positive role in increasing goldfish immunity against $A$. hydrophila. The increase in RBC levels, which reflects increases in derived indices for the infected group, may be caused by the production of younger, immature RBCs with less $\mathrm{Hb}$ content in green chromide infected with epizootic ulcerative syndrome [30].

In contrast, mixed herbal treatment should be used with caution since it also leads to physiological disruptions. For example, the ethanolic leaf extract induces an increase in total and differential leukocyte counts in rats [31], an increase in RBC counts, a reduction in RBC membrane thickening, and an increase in membrane fluidity [32]. For MCV, after the infection, the haematological indices were resulted with no significantly difference $(\mathrm{P}>0.05)$. Although no significant differences were observed, it could be concluded that infected fry suffered from hypochromic microcytic anaemia [33]. It clearly suggested that a hemodilution mechanism has occurred. The MCV gave an indication of the status or size of the RBC and reflected an abnormal or normal cell division during erythropoiesis [34].

On the other hand, MCHC results on days 60 showed there were significant differences $(\mathrm{P}<0.05)$ compared to the control group. The significant decrease in the MCHC in this study was an indication of erythrocytes swelling and/or due to a decrease in haemoglobin synthesis in control group [33]. Buckley JA, et al. [35] reported that prolonged reduction in haemoglobin content was deleterious to oxygen transport and any blood dyscrasia and degeneration of the erythrocytes could be ascribed as pathological conditions in fishes exposed. The biochemical parameter of ALT and ALP were significantly affected by mixed-herbal supplementation. Pre-challenge, ALT showed significant different in all treatment, compared to significant decreases at post challenge. However at the pre- challenge, ALP revealed only AVE and SCE with no significantly difference compared to the control group. Then at the post challenge all mixed herb showed decreases in ALP value, however control treatment showed a significant increases. There was a significant $(\mathrm{P}<0.05)$ decrease in ALT and ALP post challenge, compared to the control group. The AST, showed significant difference among all treatments, with control treatment not showing any significant difference at pre and post challenge. Post challenge, AVE and VTE showed no significant difference compared to the control group. 
Citation: Manaf SR, Daud HM, Alimon AR, Mustapha NM, Hamdan RH, et al. (2016) The Effects of Vitex trifolia, Strobilanthes crispus and Aloe vera Herbal-mixed Dietary Supplementation on Growth Performance and Disease Resistance in Red Hybrid Tilapia (Oreochromis sp.). J Aquac Res Development. 7: 425. doi:10.4172/2155-9546.1000425

\section{Conclusion}

In conclusion, the combination of AVE and VTE is the most significantly improved growth of Oreochromis sp. juveniles and also reduces the mortalities post challenge with $S$. agalactiae. The present results suggested that the mixed herbal supplementation feeds are responsible for maintaining the haematological and biochemical parameters to normal condition and further improve to trigger the immune system of the innate immunity of Oreochromis sp. against S. agalactiae when supplemented with $7 \mathrm{~g} / \mathrm{kg}$ DM of mixed herbal. However, the exact mechanism of inducing the blood parameter recoveries and innate immune response using modern molecular techniques should be applied to ensure that the species of mixed herbal supplementation feeds used in aquaculture are correctly identified, for quality assurance as well as safety.

\section{Acknowledgment}

The authors would like to thank UiTM for the scholarship.

\section{References}

1. Dada AA (2015) Improvement of tilapia (Oreochromis niloticus Linnaeus, 1758) growth performance fed three commercial feed additives in diets. Journal of Aquaculture Research and Development 6: 325-327

2. Zilberg DA, Tal N, Froyman S, Abutbul DN, Golan-Goldhirsh A (2010) Dried leaves of Rosmarinus officinalis as a treatment for Streptococcosis in tilapia. Journal of Fish Diseases 33: 361-369.

3. Farahi A, Kasiri M, Sudagar M, Soleimani IM, Zorriehzahra SMJ (2012) Effect of dietary supplementation of Melissa officinalis and Aloe vera on hematological traits, lipid oxidation of carcass and performance in rainbow trout (Oncorhynchus mykiss). Online Journal of Animal and Feed Research 2: 1-5.

4. Dada AA, Olugbemi BD (2013) Dietary effects of two commercial feed additives on growth performance and body composition of African catfish Clarias gariepinus fingerlings. African Journal of Food science 7: 325-328.

5. Rios JL, Recio MC (2005) Medicinal plants and antimicrobial activity. Journal of Ethnopharmacology 100: 80-84.

6. NRC (National Research Council) (1993) Nutritional Requirements of Fish National Academy Press, Washington, DC, USA

7. Soosean C, Marimuthu K, Sudhakaran S, Xavier R (2010) Effect of mangosteen (Garcinia mangostana L.) extracts as a feed additive on growth and hematological parameters of African catfish (Clarias gariepinus) fingerlings. European Review for Medical and Pharmacological Sciences 14: 605-611.

8. Rawling MD, Merrifield DL, Davies SJ (2009) Preliminary assessment of dietary supplementation of Sangrovit ${ }^{\circledR}$ on red tilapia (Oreochromis niloticus) growth performance and health. Aquaculture 294: 118-122.

9. Akinwole AO, Faturoti EO (2007) Biological performance of African catfish (Clarias gariepinus) cultures in recirculating system in Ibadan. Aquaculture Engineering 36: 18-23.

10. Duncan DB (1955) Multiple range and multiple 'F' tests. Biometrics 11: 1-42.

11. Brown J (1989) Antibiotics: their use and abuse in aquaculture. World Aquaculture 20: 34-43.

12. Citarasu T, Rajajeyasekar R, Venketramalingam K, Dhandapani PS, Marian MP (2003) Effect of wood apple Aegle marmelos, Correa (Dicotyledons, Sapindales, Rutaceae) extract as an antibacterial agent on pathogens infecting prawn (Penaeus indicus) larviculture. Indian Journal of Geo-Marine Sciences 32: $156-161$

13. Jayaprakas V, Eupharsia J (1996) Growth performance of Labeo rohita (Ham.) Livol (IHF-1000) an herbal product. Proceedings-Indian National Science Academy 63: 1-10

14. Cristea V, Antache A, Grecu I, Docan A, Dediu L, et al. (2012) The use of phytobiotics in aquaculture. Lucrari Stiintifice-Seria Zootehnie 57: 250-255.

15. Citarasu T, Sivaram V, Immanuel G, Rout N, Murugan V (2006) Influence of selected Indian immunostimulant herbs against white spot syndrome virus (WSSV) infection in black tiger shrimp, Penaeus monodon with reference to haematological, biochemical and immunological changes. Fish Shellfish and Immunology 21: 372-384

16. Ji SC, Takaoka O, Jeong GS, Lee SW, Ishimaru K, et al. (2007) Dietary medicinal herbs improve growth and some non-specific immunity of red sea bream Pagrus major. Fisheries Science 73: 63-69.

17. Aditya K, Ravi Kumar A (2014) Phytochemical evaluation of Vitex leuocoxylon Vitex negundo and Vitex trifolia. Indian Journal of Research in Pharmacy and Biotechnology 2: 1106-1108.

18. Arunkumar S, Muthuselvam M (2009) Analysis of phytochemical constituents and antimicrobial activities of Aloe vera L. against clinical pathogens. World Journal of Agricultural Sciences 5: 572-576.

19. Nurraihana H, Norfarizan-Hanoon NA (2013) Phytochemistry, pharmacology and toxicology properties of Strobilanthes crispus. International Food Research Journal 20: 2045-2056.

20. Ebong PE, Atangwho IJ, Eyong EU, Egbung GE (2008) The antidiabetic efficacy of combined extracts from two continental plants: Azadirachta indica (A. Juss) (Neem) and Vernonia amygdalina (Del.) (African Bitter Leaf). American Journal of Biochemistry and Biotechology 4: 239-244.

21. Ceulemans $S$, Robles R, Coutteau $P$ (2009) Innovative feed additives improve feed utilization in Nile Tilapia. Global Aquaculture Advocate.

22. Citarasu T, Micheal BM, Raja Jeya SR, Peter MM (2002) Developing artemia enriched herbal diet for producing quality larvae in Penaeus monodon, Fabricius. Asian Fisheries Science 15: 21-32.

23. Punitha SMJ, Babu MM, Sivaram V, Shankar VS, Dhas SA, et al. (2008) Immunostimulating influence of herbal biomedicines on nonspecific immunity in Grouper Epinephelus tauvina juvenile against Vibrio harveyi infection Aquaculture International 16: 511-523.

24. Jian J, Wu Z (2003) Effects of traditional Chinese medicine on nonspecific immunity and disease resistance of large yellow croaker, Pseudosciaena crocea (Richardson). Aquaculture 218: 1-9.

25. Ponpornpisit A, Endo M, Murata H (2001) Prophylactic effects of chemicals and immunostimulants in experimental Tetrahymena infections of guppy. Fish Pathology 36: 1-6.

26. Chen X, Wu Z, Yin J, Li L (2003) Effects of four species of herbs on immune function of Carassius auratus gibelio. Fish Sciences China 10: 36-40.

27. Sivaram V, Babu MM, Immanuel G, Murugadass S, Citarasu T (2004) Growth and immune response of juvenile greasy groupers (Epinephelus tauvina) fed with herbal antibacterial active principle supplemented diets against Vibrio harveyi infections. Aquaculture 237: 9-20.

28. Nya EJ, Austin B (2009) Use of garlic, Allium sativum, to control Aeromonas hydrophila infection in rainbow trout, Oncorhynchus mykiss (Walbaum). Journa of Fish Diseases 32: 963-970.

29. Harikrishnan R, Rani MN, Balasundaram C (2003) Hematological and biochemical parameters in common carp, Cyprinus carpio, following herbal treatment for Aeromonas hydrophila infection. Aquaculture 221: 41-50.

30. Pathiratne A, Rajapakshe W (1998) Hematological changes associated with epizootic ulcerative syndrome in the Asian cichlid fish Etroplus suratensis. Asian Fishery Science 11: 203-211.

31. Archana R, Namasivayam A (2000) Effect of Ocimum sanctum on noise induced changes in neutrophil function. Journal of Ethnopharmacology 73 81-84

32. Sen P, Maiti PC, Puri S, Ray A (1992) Mechanism of anti-stress activity of Ocimum sanctum Linn, eugenol and Tinospora malabarica in experimental animals. Indian Journal of Experimental Biology 30: 596-604.

33. Zorriehzahra MJ, Hassan MD, Gholizadeh M, Saidi AA (2010) Study of some hematological and biochemical parameters of Rainbow trout (Oncorhynchus mykiss) fry in western part of Mazandaran province, Iran. Iranian Journal of Fisheries Sciences 9: 185-198.

34. Nussey G, Van Vuren JHJ, Du PHH (2000) Bioaccumulation of chromium, manganese, nickel and lead in the tissues of the moggel, Labeo umbratus (Cyprinidae), from Witbank Dam, Mpumalanga. Water Sinces 26: 269-284.

35. Buckley JA, Whitmore CM, Matsuda RI (1976) Changes in blood chemistry and blood cell morphology in coho salmon, Oncorhynchus kisutch following exposure to sub-lethal levels of total residual chlorine in municipal wastewater. Journal of Fish Research Board Canada 33: 776-782. 